\title{
中国語文の声域に関する若干の考察
}

志賀 正 年

中国語文を，声を出して音読したり，声高 く朗梳したりした場合の，声城の性態はどの ようであるか？この課題と取り組む一方策 として，今般，素材を中国唱片社発行の L P

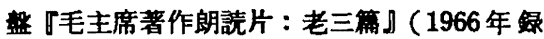
音）と，1968年北京贯播学院吹き込みのテー プ毛沢東語塂一テキスト版』とに求めた。 しかも，朗読上の比玟考察を意图する見地
に甚つき，最初の予偳作業として，(1) 1968 年 4 月毛沢東著作言語研究会編・株式会社大 安刊の『毛沢東铻唋テキスト版』と，1967年 1 月中国人民解放軍総政治部編印・新華㙋店 刊の『毛主席語録』との字数調查を果たし た。

その対比結果を表示寸れば，つぎのと捛り である。

\begin{tabular}{|c|c|c|c|c|c|}
\hline 章名豆名 & \multicolumn{2}{|c|}{$\begin{array}{l}\text { 毛沢東語録 } \\
\text { 華キスト版 }\end{array}$} & \multicolumn{2}{|c|}{ 毛主席語録 } & 毛主席語疑「計」 \\
\hline- & (10節) & 762 字 & [ 3節] & 336字 & $<13$ 節 $>1,098$ 字 \\
\hline 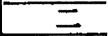 & (19) & 1,975 & [3] & 369 & $\langle 22\rangle \quad 2,344$ \\
\hline 三 & (3) & 441 & {$[25]$} & 3,694 & $\langle 28\rangle \quad 4,135$ \\
\hline 四 & 4) & 486 & [12] & 1,968 & $\langle 16\rangle \quad 2,454$ \\
\hline 五 & (16) & 1,809 & [5] & 683 & 2,492 \\
\hline 六 & (9) & 1,637 & 1] & 97 & 1,734 \\
\hline$t$ & (6) & 399 & 4] & 445 & $<10\rangle$ \\
\hline 八 & 4) & 322 & {$[6]$} & 1,712 & $\langle 10\rangle$ \\
\hline 九 & 3) & 228 & [5] & 545 & $\langle 8\rangle$ \\
\hline+ & 3) & 380 & [11] & 1,926 & $\langle 14\rangle$ \\
\hline+- & 5) & 386 & [17] & 2,378 & $\langle 22\rangle$ \\
\hline$+=$ & 4) & 256 & [17] & 1,796 & $\langle 21\rangle$ \\
\hline$+\equiv$ & (2) & 132 & {$[5]$} & 524 & $\langle 7\rangle$ \\
\hline 十四 & (2) & 128 & 4] & 299 & $\overline{427}$ \\
\hline 十五 & 1) & 104 & 5] & 835 & 939 \\
\hline 十六 & 2) & 118 & 7] & 344 & 462 \\
\hline$+t$ & 8) & 557 & {$[1]$} & 38 & 595 \\
\hline$+\lambda$ & 5) & 903 & 2] & 279 & 1,182 \\
\hline +九 & 5) & 210 & 3] & 454 & 664 \\
\hline 三t & (2) & 190 & 6] & 938 & 1,128 \\
\hline 三十一 & (11) & 1,231 & [2] & 138 & 1,369 \\
\hline 二十二 & (15) & 1,342 & [26] & 3,483 & $\langle 41\rangle \quad 4,825$ \\
\hline 二十三 & $(2)$ & 263 & {$[7]$} & 968 & 1,231 \\
\hline 三十四 & 4) & 473 & [11] & 1,971 & 2,444 \\
\hline 二十五 & 2) & 147 & [3] & 207 & 354 \\
\hline 二十六 & 2) & 243 & {$[3]$} & 179 & 422 \\
\hline 二t七 & 5) & 664 & {$[10]$} & 995 & 1,659 \\
\hline 三十八 & 7) & 574 & [11] & 591 & $<18>$ \\
\hline 二十九 & (3) & 1,109 & {$[8]$} & 1,096 & 2,205 \\
\hline$\equiv+$ & (2) & 225 & [5] & 715 & 940 \\
\hline 三十- & $(1)$ & 76 & [6] & 600 & 676 \\
\hline 三十三 & (6) & 411 & {$[2]$} & 485 & $\langle 8\rangle$ \\
\hline 三十三 & (10) & 938 & [6] & 457 & $\langle 16\rangle$ \\
\hline
\end{tabular}


「满考」

（1）本表は，実字（章および出典の 文字や，標点符号は計算外）だけを示し た数字である。ちなみに『毛主席語鉎』 の奥きでは，字数88,000字となってい る。

（2）本表の權成は，(1) 毛沢東語䩮テ キスト版+(2)毛主席語録ー(3)毛主席語録 「計」であり，(3)の計を100\%とすれば， (1)は37.7\%，(2)は62.3\%を占めている。 そして，(2)の62.3\%に同する内容を考宗 するに，主として，中国人民を対象とし た指示中報告・教訓や譜萿等一例とし て1934年 1 月23日《我們的經洲政策》, 1936年12月《中国革命解争的戦略問題》
1939年 1 月《中国革命和中国共産党》, 1955年 5 月《闺于胡風反革命集団的材 料》, 1657年 2 月 27 日《成于正碓如理人 民内部矛盾的問题》, 1957 年 3 月 12 日

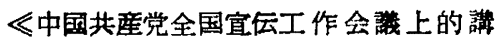
嶉》など——であり，日本人向きには， 第二壀的な語绿に属するものゆえ，(1)に 含めなかったものか，と察せられる。

(2) 朗誖材としての两者，すなわら， L P 盤『老三筒』と録音テーフ『毛沢東語録』(テ キスト版）との声城比校を果たすための基硬 作菜として，両者の一致語睩を照合し集録し てみた。その所座は，次表の(1)ー(12（たたし 字数順に小〜大へ並べかえた）のとおりであ る。

\section{[実蜸算料 门]}

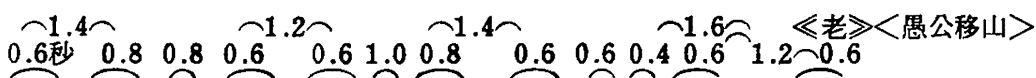

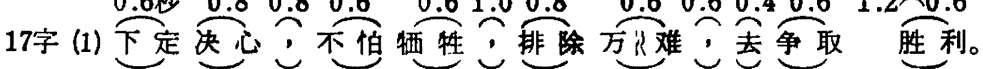

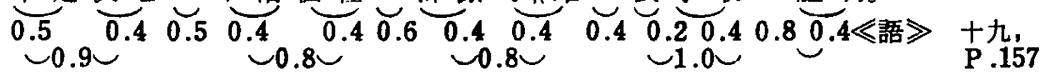

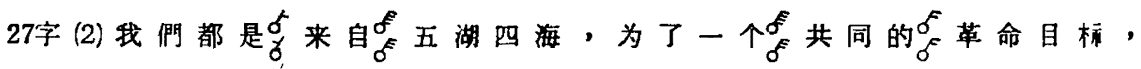
走到一起来了。《老》〈为人民服务>

29 字 (3) 我們的同志 $\hat{\circ}^{+}$在困难的时候, 要看到成縜, 要看到光明, 要提高我們的勇气。

$$
\text { 《部》三十二, P.170 }
$$

35 字 (4) 我們的干部点要关心毎一个战士，一切革命队伍的人气都要 互相关心, 互相爱护, “互相帮助。《語》十三, P.129

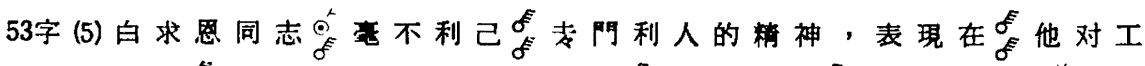

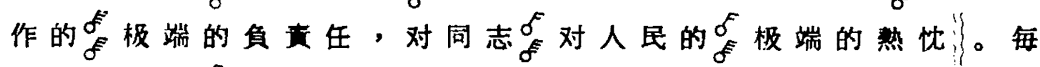

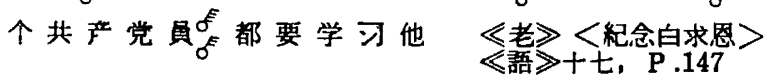

55 字 (6) 我們的共产党 $\hat{E}_{E}^{\circ}$ 和共产党所領㞯的 $\sigma_{\delta}^{\delta}$ 八路軍, 新四軍, 是革 命的队伍。我們这个队伍丐完全是为着否解故人民的，是彻

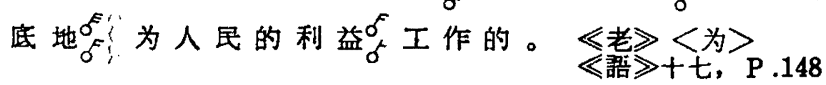

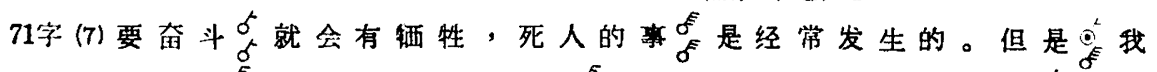

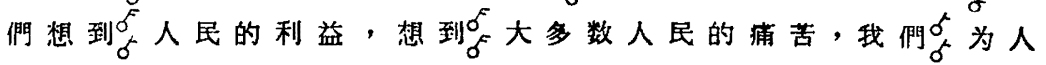




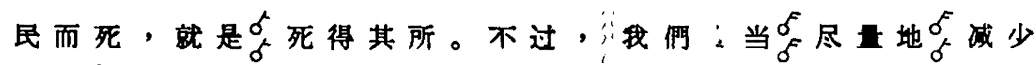
那些矣不必要的徆性。《老》十为> P.149

72 字 (8) 因为否我們是疋为人民服务的, 所以, 我們如果有缺点, 就 不怕歪则人批諳指出。不管占是什么人, 谁向我們指出都 行。只要占你説得对, 我們就改正彴。你説的办法桌对人民有 好处, 我們就照你的办。 $\ll$ 考》三为〉, P .228

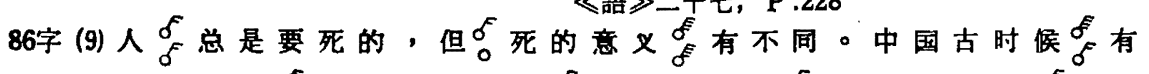

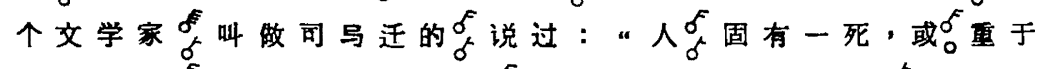
泰山, 或 $\delta^{\delta}$ 㹩于鴻毛。”为矣人民利益而死, 就比占泰山还

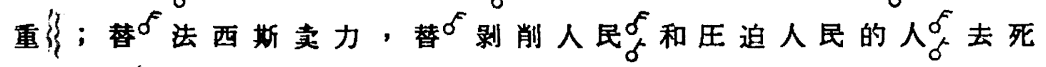

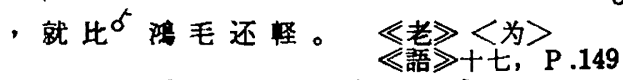

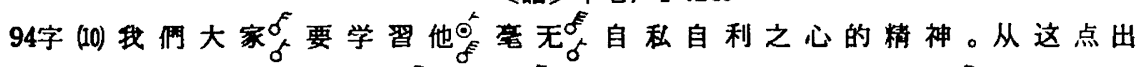

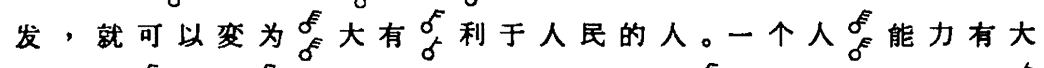

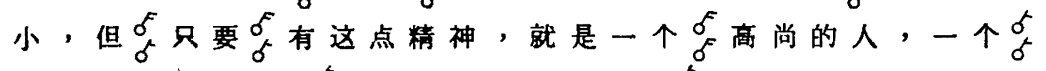
純粋的人?, 一个宗有道德的人, 一个察脱离了低刺趣味的 人, 一个察有益于人民的人。发》紀〉

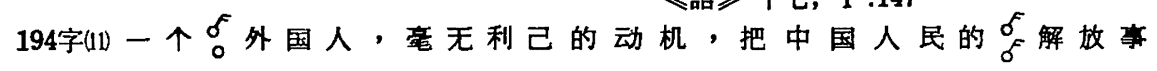

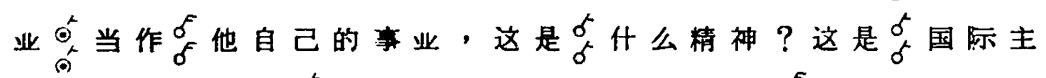
义的精神, 这是矣共产主义的精神, 毎一个占中国共产党

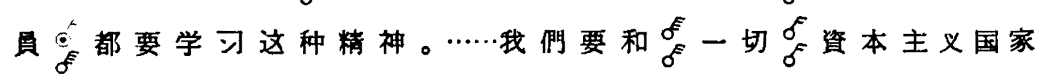

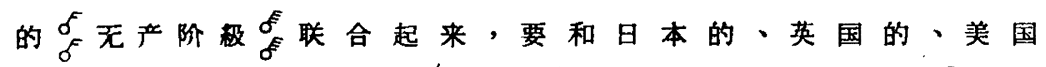

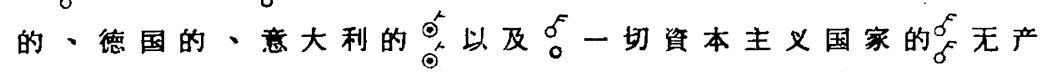

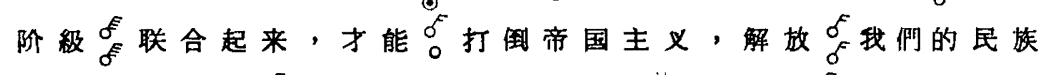
和人民, 解放矣世界的民族和人民。这就是矣我們的国际

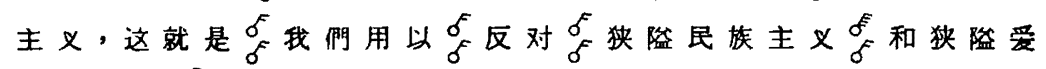

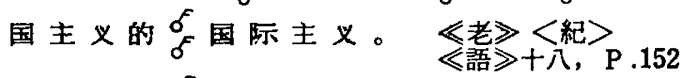

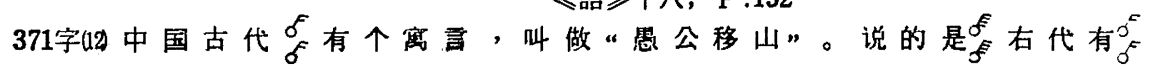

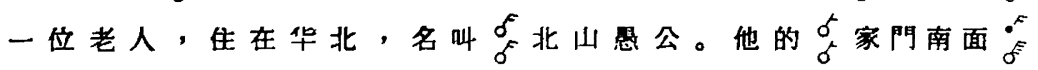
有两座大山告挡住他家的出路, 一座矣叫做太行山, 一座桌 


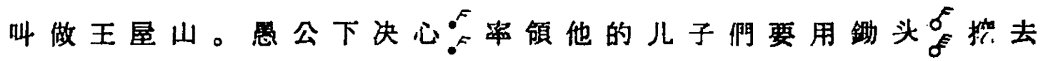

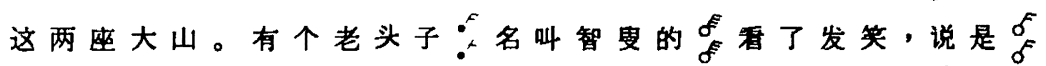

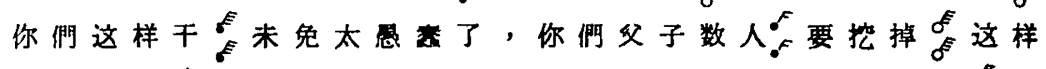

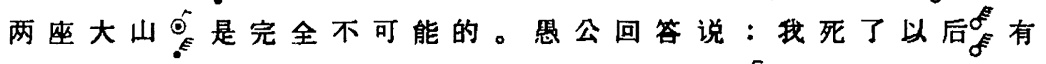
我的儿子, 儿子死了, 又有孙子, 子子孙孙毎是没有穷尽的。

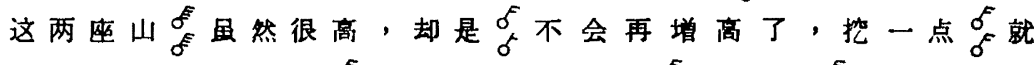

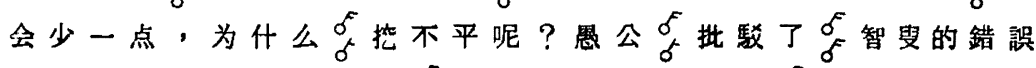

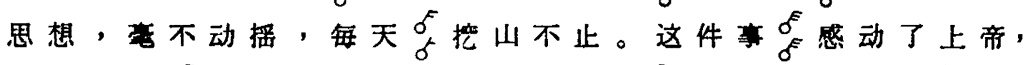

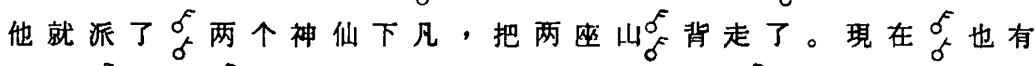

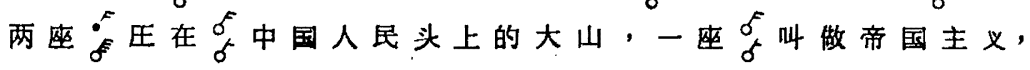
一㭫占叫做封建主义。中国共产党年早就下了决心, 多要挖

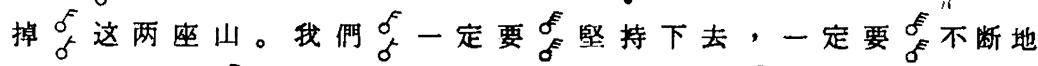
工作, 我們占也会感动上帝的。这个上帝占不是別人, 就

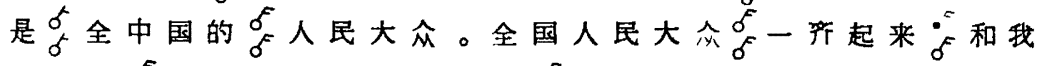
們一道尔挖这两座山, 有什么宗挖不平呢?

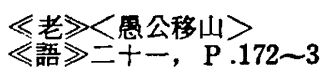

注 (1) Breath 測定記号…… 0.05 秒 o 0.1 秒 •`0.5秒 ○ 1.0 秒

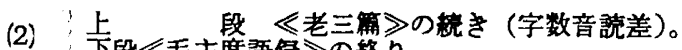

(3) 上段略称の《老》は《老三筒》, $<$ 为 $>$ は $<$ 为人民服务 $\rangle,<$ 紀 $>$

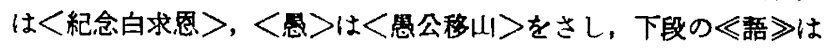
《毛主席語録》をさし，なおまた数字は，章・ベージ数を示してい る。

(4) 一致語録は，如上の (1)—02のはかに，も5一つ119字(43)不少的人对 工作不目黄任，…至少不能算一个純料的共产党員。

$\ll$ 老》<紀 >

《語》二十四, P . 207 8

の個所も見かけられたが，下段《語》の䟿音が無いために比較でき ずやむをえず割爱した次第である。

この〔実験筫料 I〕(1)〜 12にによって, 同 一の朗読材であるにもかかわらず，上段の 《老》と下段の《語》との朗読法を比较する とき, 諸般にわたる相連点が琹められる。笔 者は, それらの相连点を検索する方途とし て、視点を1.声域の厇狭振幅度 時間測定
に䔄つく(1)朗読速度の影整による声域の広怢 度，(口) 標点符号を対象とした振幅度一日。 声域の諸性䈍——Pause - Breath Group • Intonation - Pitch - Stress etc. 一に求 ぬ，以下順を追って，若干の論証を果たそう と思5。 


\begin{tabular}{|c|c|c|c|c|c|c|c|c|c|c|c|c|c|}
\hline № & (1) & (2) & (3) & (4) & (5) & (6) & (7) & (8) & (9) & (10) & (ii) & (12) & 晴 \\
\hline & & 27 & 29 & 35 & 53 & 55 & 71 & 72 & 86 & 94 & 194 & 371 & \\
\hline$=-7$ 性 别 & 女 & 男 & 男 & 男 & 䙲 & 男 & 男 & 穷 & 男 & 男 & 9 & $x$ & \\
\hline \begin{tabular}{l|ll} 
段 & 所 & 要 \\
名》分
\end{tabular} & 8 & 8.2 & 11.4 & $\begin{array}{c}13 \\
\text { 秒 }\end{array}$ & 21.2 & 18.5 & \begin{tabular}{|c|}
26 \\
秒
\end{tabular} & 27.25 & 38.2 & \begin{tabular}{|c|}
35 \\
秒
\end{tabular} & 1 分 & \begin{tabular}{|r|}
2 分 \\
26.2 列
\end{tabular} & 4.3 \\
\hline 性 别 & 男 & 女 & 男 & 女 & 男 & 女 & 男 & 勇 & 女 & 男 & 女 & 男 & \\
\hline 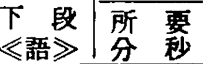 & 秒 & 7 . & 8.31 & 11 秒 & $\begin{array}{c}16 \\
\text { 秒 }\end{array} \mid$ & 17.2 & 21 移 & 21 & & $\mid 25.2$ & '59秒 & 1 分 & $\begin{array}{r}5 \text { 分 } \\
39.1 \text { 秒 }\end{array}$ \\
\hline 差 分 秒 & $\begin{array}{l}3 \\
\text { 秒 }\end{array}$ & 0.6 & 秒 & $\begin{array}{r}1.8 \\
\text { 秒 }\end{array}$ & \begin{tabular}{|c|}
5.2 \\
秒
\end{tabular} & \begin{tabular}{|c|}
1.3 \\
秒
\end{tabular} & \begin{tabular}{|c|}
4.8 \\
秒
\end{tabular} & 6.2 & $\begin{array}{c}10 \\
\text { 秒 }\end{array}$ & \begin{tabular}{|c|}
9.8 \\
秒
\end{tabular} & 1 & 27秒 & $\begin{array}{r}1 \text { 分 } \\
25.5\end{array}$ \\
\hline 差字 数 & 6 字 & 2 & 8 & 4 & 11 & 9 & 17 & 18 & $\begin{array}{l}26 \\
: n\end{array}$ & 27 & 37 & $\begin{array}{c}78 \\
0 \times 3^{\prime} \times 4 ?\end{array}$ & $\begin{array}{r}243 \text { 字 } \\
: ?, \times 120 \times 5\end{array}$ \\
\hline
\end{tabular}

上揭の(贯料】〕に基つき，a．差分秒に ついて, b. 差字数について, c . 性别につ いて，の順に考察を進めてみよう。

\section{a. 差分秒について}

《老》の所要分秒計 7 分 4.3 秒と《語》の 計 5 分39.1秒との間沪法， 1 分25.2秒の分秒 差が珰められる。そして，実字数 (1) 17字の 場合の（8秒：5秒） 3 秒差は，23\%に相当 するが，杖 371字の場合の（2 分26.2秒：1 分59.2眇）の27秒差は，0.88\%にしかすぎな い一事例仼して，差分秒は，かならすし も実字数の增加とは正比例しない点がが判明 した。そこには，種々の要因が存しそれら が速度の悢急に伴ら声城の広狭を生むに至る むの, と言える。

\section{b. 差字数について}

実字数差では, 計 1,104 字に対する $22 \%$ （243字）に相当している。なおこれには標 点符号差—(1)・(5)・ (8)・ (9)・ (10)・ (11) ・ (12)計 $(: ? \mid, \times 12)+(\circ \times 5)$ 6含立れ小
ク，この差字数面でも，(1)〜(12)間に若下のふ そろいが琹められる。さらにまた，差字数と 美分秒との関係を調へるに，1 分25.2秒+ 243 字 $=0.35$ 秒となり，この一字平均秒数面か らの增减仕訳を試及るに，(1)・(3)・(4)・(5)・

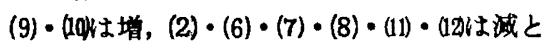
なっている。

\section{c. 性別について}

吹き込及録音者の性別（男・女）を㭘討 寸るに, イ。男: 男 $[(3) \cdot(5) \cdot(7) \cdot(8) \cdot(10)]$ 口. 男 : 女 $[(2) \cdot(4) \cdot(6) \cdot(9) \cdot(11)] 八$. 女: 男〔(1)・(12)の三種類が琹められる。け だし, 語文の朗読には, 他の演説・宣言・報 告等とは遗ったりズムや抑掦があり，それが 同時に，性別・個人別による声域の広狭度と も因果関係を成して, 声城の漛相・性態にあ る種の差異を生せしめている。

い主仮に，《老》の辡及かたを 甲. 朗読

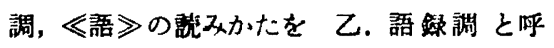
称し，両者の比䑤を示すならば，

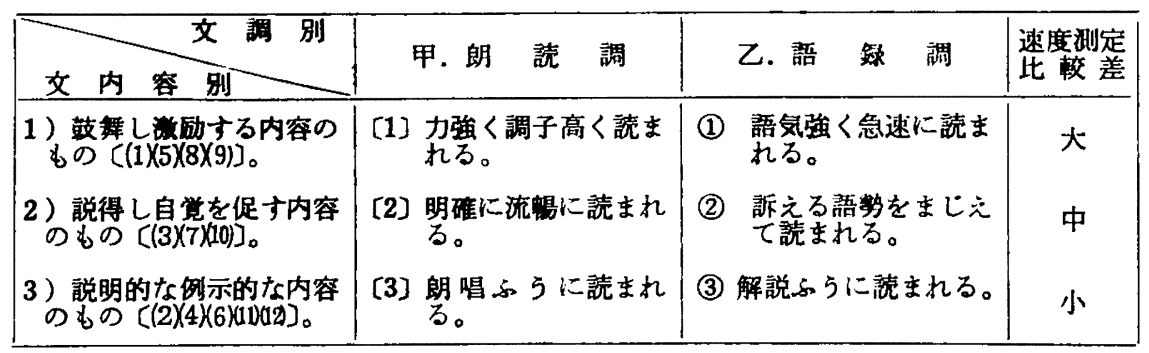


のごとくである。

さらに，性别比較盖としては，

\begin{tabular}{|c|c|c|}
\hline 性别 & 甲. 朗 読 & 乙. 語 \\
\hline 男 & $\begin{array}{l}\text { プセントが明確で，リ } \\
\text { ズミカルである。 }\end{array}$ & 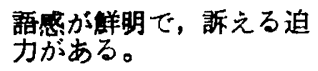 \\
\hline 女 & $\begin{array}{l}\text { ピッチが高く，声質に伸 } \\
\text { びがある。 }\end{array}$ & $\begin{array}{l}\text { 語調が早めで, なめらか } \\
\text { である。 }\end{array}$ \\
\hline
\end{tabular}

の锗点を指摘することができる。

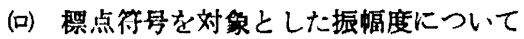

(资料 四)

\begin{tabular}{|c|c|c|c|c|c|c|}
\hline \multirow{2}{*}{ 区分 } & \multirow{2}{*}{ 採点符号 } & 半引号 & 頓 号 & 逗 & 句 & 分 号 \\
\hline & & “. & v & , & $\circ$ & ; \\
\hline \multirow{3}{*}{$\ll$ 老》 } & 出現 度 数 & 1 & 5 & 73 & 22 & 2 \\
\hline & 平均秒数 & 0.4 秒 & 0.86 & 1.08 & 1.8 & 2.0 \\
\hline & 短一中心一長 & 0.4 & $0.3-1.0$ & $0.6-1.0-1.2-2.2$ & $1.4-2.0-3.0-3.2$ & 2.0 \\
\hline \multirow{3}{*}{ 《語》 } & 出現 度 数 & 1 & 5 & 73 & 22 & 2 \\
\hline & 平均秒数 & 0.3 秒 & 0.78 & 0.919 & 1.68 & 1.5 \\
\hline & 短一中心一長 & 0.3 & $0.3-0.8-1.0$ & $0.4-0.8-1.0-1.5$ & $1.0-1.4-2.0-2.8$ & $1.2-1.8$ \\
\hline
\end{tabular}

\begin{tabular}{|c|c|c|c|c|c|c|c|}
\hline \multirow{2}{*}{ 区 分 } & 採点符查 & 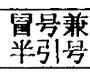 & 問 号 & 半引睜句 & $\begin{array}{l}\text { 句豆兼 } \\
\text { 半引忿 }\end{array}$ & 省略号 & \multirow{2}{*}{ 幛 } \\
\hline & & $: \quad \cdots$ & $?$ & $" 0$ & $\circ "$ & $\ldots \ldots \ldots$ & \\
\hline \multirow{3}{*}{$\ll z 》$} & 出現度数 & 1 & 2 & 1 & 1 & & 108 \\
\hline & 平均秒数 & 2.2 & 2.6 & 3.0 & 3.2 & & \\
\hline & 短一中心一艮 & 2.2 & $2.2-3.0$ & 3.0 & 3.2 & & \\
\hline \multirow{3}{*}{ 《語》 } & 出. 現度数 & 1 & 2 & 1 & 1 & 1 & 109 \\
\hline & 平均秒数 & 1.2 & 2.0 & 1.6 & 1.2 & 2.2 & \\
\hline & 短一中心一長 & 1.2 & $1.4-2.6$ & 1.6 & 1.2 & 2.2 & \\
\hline
\end{tabular}

上揭の〔筫料田)は，《老》《語》中に 出現する標点符号の洔間態を测定した所産で ある。硛間態の测定分析は，まず第一に，各 出現度数中の最短秒数と最長秒数とを揭获， ついで中心秒数を示したのち，さらに全分秒 数 $\div$ 出現度数=平均秒数を抽㑁寸る力法に従
った。そして，標点符号の排列順は，《老》 部門の平均尖数による短 $\rightarrow$ 長の順位を示した ものであり，ちなみに，《語》部門の排列㮌 では, 半引号, 頓号, 通号, 句号, 冒号兼半 引号・句号兼半引号, 分号, 半引号兼句号, 問号, 省略号となる。 
けだし，票符号の，言語との网係におい て果たす機能は，第一義的には，语面語文に 付加して，その詁尔・毒写を助ける点にある とはいえ，口頭震語の場にあっても，表現伝 逵上の停頓・中断・沈然・語気・器調等を感 受し合えるための，一電格別な役割りを果た すものと需える*。

*拙論「中国語文の声域考一一特に策点符 号の時間臨について一」(1969年 1 月 刊 『中文研究』 No.9 収裁)の一文は,『ソノシ 一ト現代中国語朗洒第』（1965年4月中国 晿片厥刊) 中の五一郭洙若作「天上的
街市」，售迅作「立論」，牧野作「“㙂明的” 外科医生」，测竫作「木佩探海」，高玉宝作

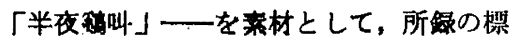
点符号総数211を細に分類し，それそれ の時间怨を論考したものである。

しかも，所措䝷料に明らかなことく，たと え同一の檈点であっても，文调别・性别によ る声域の振濡度の然らしめる所，そこにおの ずと，時间焦差を生ぜしめる，との実趾を得 た。なかんすく，出現度数が大であるく湴 号〉およびく够号>の時間隹に見られる， 《老》《語》間の美秒数, 寸なわち,

\begin{tabular}{|c|c|c|}
\hline 盖秒 点号 & & \\
\hline 平均秒数 & 0.161 秒 & 0.12 秒 \\
\hline 短一中心一段 & $0.2-0.2-0.7$ 秒 & $0.4-0.8-0.4$ 秒 \\
\hline
\end{tabular}

は，とりもなおさす，甲，乙二種の文調が起 因する声域の，代表的な振幅差を示すしのと 言えよう。

\section{| 声贱の舶性㸃について}

諸性態の内, 本构では特に Breath Group すなわち, “息維ぎ群”の性態をとらえてみ ようと思う。およて, Breath一息継きーとは
Voice一こえ一の対称哣であり, Non Punctuation Marks一無梆点符号一の文面に羿め られるむのにはかならない。

そして，この “息継き群”の性悲を分析す るための取材作柴として，䈃者はます，長字 (16字以上の) の個所を選出した。その所産 が,次表のとおりである。

\begin{tabular}{|c|c|c|c|c|c|c|c|c|c|c|c|c|c|c|c|c|c|c|c|c|}
\hline 長字数 & 16字 & ह & 17字 & 息 1 & 18字 & 息 1 & 19字 & 息 & 20字 & 息 & 21字 & 鼠 & 22字 & 息 & 23字 & 息 & 25字 & 泉 & 27字 & \\
\hline $\mathrm{Na}$. & $(5)(6)$ & & $\begin{array}{l}(6)(7) \\
\text { (1) (122) }\end{array}$ & ( & $\begin{array}{c}(9)(11) \\
(12)\end{array}$ & 楚 & (10) & 継 & 12 & 絊 & (1) & 整 & (12) & 継 & (12) & 楼 & (11) & 橉 & (11) & \\
\hline & 2 & 数 & 4 & 数 & 3 & 数 & 1 & 数 & 1 & 数 & 1 & 数 & 1 & 数 & 1 & 数 & 1 & 数 & 1 & \\
\hline 略 & $a_{1}$ & $=$ & $b^{1}$ & $=$ & $c 1$ & $\equiv$ & & & & & & & & & & & & & & \\
\hline 符 & & $\ldots$ & $b^{2}$ & $\equiv$ & $c 2$ & $\equiv$ & $d$ & $\equiv$ & $e$ & 三 & $f$ & 四 & $\boldsymbol{g}$ & $\equiv$ & $h$ & 二 & $i$ & 四 & $j$ & 五 \\
\hline & $a^{2}$ & 二 & 0 & - & & & & & & & & & & & & & & & & \\
\hline 7 & & & $b^{4}$ & $\equiv$ & $c 3$ & 三 & & & & & & & & & & & & & & \\
\hline
\end{tabular}

ついて，上表の略符号 $[a 1 \sim j\rfloor$ の内容 を明示し, “息能ぎ群”をめぐる若干の論察 を施したい。

a 1 (5)白求恩同志 | 等不利已 | 専門利人的 精神，は5|4|7，で息継ぎ二回。 a 2 (6)我們这个队伍 | 完全是为羞 | 解放人 民的，は6|5|5, で同しく二回。 $b^{1}$ (6)我們的共产党 | 和共产党所領导的

八路軍，は6|8|3，で二回。

$b^{2}$ (7)我們应当｜尽些地｜诚少那些｜不必 要的洒制。は，4|3|4|6。で三回。 $b^{3}$ (1)毎一个| 中国共产党員 | 都要学習这 种精神。は， $3|6| 8$ 。で二回。 b4 12現在 | 也有两坐 | 圧在 | 中国人民头 
上的大山,は，2|4|2|9，で三回。 c1 (9)中国古时候｜有个文学家|叫做可号 迁的 | 説过：は，5|5|6|2：で三回。 c 2 (11)把中国人民的 | 解放事业 | 当作 | 他 自己的事业，は，6|4|2|6，で三回。 c 3 12他的 | 家門南面 | 有两座大山 | 挡住 他家的出路，は，2|4|5|7,で三回。 $d(10)$ 我們大家 | 要学習他 | 些无 | 自私自利 之心的神。は，4|4|2|9。で三回。 $e$ (12)全国人民大众 |一齐起来|和我們一道 | 这两座山，は，6 $64|5| 5$, で 三回。

$f($ (1)我們要和 |一切|曾本主义国家的 |无 产阶級 |联合起来, は, 4 | 2 | 7 | 4 | 4.で四回。

$g$ (12)你們父子数人 | 要挖掉 | 这样两坐大山 | 是完全不可能的。は, 5|3|6|7。で 三回。

$h$ (12思公下决心|事項他的儿子們要用鋤头

| 挖去这两座大山。は，5 | 11|7。で 二回。

$i$ (13)以及意大利的 |以及 以一切資本主义国 家的 |无产阶級|联合起来, は，6 12

| 9 | $4 \mid 4$, で四回。

$j$ (11)这就是 | 我們用以 | 反对 | 㹟䧍民族主 义 | 和狭险爱国主义的 | 国际主义。は,

3|4|2|6|8|4。で五回。

さて, 上揭の長字内容を梳括して㭘討を試 みるに，艮字総数は311字であり，息継ぎ回 数小計 $47+$ 標点合計 $16=$ 合計 63 回であった。 したがって，311字+63回=1回の平均字数 は 5 字弱となる。この平均字数 5 に奣らして 長・短を検索するに，既の部に属するものと
乙て, 11 字 $(h), 9$ 字 $\left(b^{4} \cdot d \cdot i\right), 8$ 字 $\left(b^{1} \cdot b^{3} \cdot j\right), 7$ 字 $\left(a^{1} \cdot c^{3} \cdot f \cdot\right.$ $g \cdot h)$, 短の部に属するものとして, 2 字 $\left(b^{4} \times 2 \cdot c^{1} \cdot c^{2} \cdot c^{3} \cdot d \cdot f \cdot i \cdot j\right)$, 3 字 $\left(b^{1} b^{2} \cdot b^{3} \cdot g \cdot j\right)$ をあげること ができる。

如上の諸データーに基つき，声域に見られ る“息継ぎ群”に関して，次記のことき印象 ないし㑯向が瑟められた。すなわち，

$<1>$ 文脈の支柱一主語・述語・軍語一间 に存する息継ざ。

$<2>$ 敒飾語句・提示棓句・長めの接統句 に見られる息継ぎ。

<3>声量・呼吸による息継ぎ。

<4>心理表現に上る息継き。

などが主要を成し，さらに詳説を加えるな らば，〈1〉〈2〉の準奶は，长短の别なく交意 にあり，〈3〉は，長めの抑揚による生理的息 継ぎ，〈4〉は, 語煭・文調の強弱によるも のと言えよ5。

最後に付言として，今回の実験研究に臨み , 電気工学面から所要の筫料若干枚を作成 し，考察の具に併用した。その資料は，䎑音 テーブを, フィリカの KAY ELECTRIC Co. 制作の 6061 A型 SONAGRAM (音声分 析装買）にかけて印成したものであるが， 面の都合上, 今回はその解明を略に付し，後 日の機会にゆたねねたい。

「付記了本稿は, 昭和 43 年10月10日舜知大 学で開催された，本会第19回全国大会 の個人発表の部で，報告した内容をま とめたものである。 